\title{
Management of Dark Fermentation Broth via Bio Refining and Photo Fermentation
}

\author{
Karolina Kucharska*(D), Patrycja Makoś-Chełstowska (D), Edyta Słupek (D) and Jacek Gębicki (D) \\ Department of Process Engineering and Chemical Technology, Faculty of Chemistry, \\ Gdansk University of Technology, G. Narutowicza St. 11/12, 80-233 Gdańsk, Poland; \\ patrycja.makos@pg.edu.pl (P.M.-C.); edyta.slupek@pg.edu.pl (E.S.); jacgebic@pg.edu.pl (J.G.) \\ * Correspondence: karkucha@pg.edu.pl
}

check for updates

Citation: Kucharska, K.; MakośChełstowska, P.; Słupek, E.; Gębicki, J. Management of Dark Fermentation Broth via Bio Refining and Photo Fermentation. Energies 2021, 14, 6268. https://doi.org/10.3390/en14196268

Academic Editor: Byong-Hun Jeon

Received: 24 August 2021

Accepted: 30 September 2021

Published: 1 October 2021

Publisher's Note: MDPI stays neutral with regard to jurisdictional claims in published maps and institutional affiliations.

Copyright: (c) 2021 by the authors. Licensee MDPI, Basel, Switzerland. This article is an open access article distributed under the terms and conditions of the Creative Commons Attribution (CC BY) license (https:// creativecommons.org/licenses/by/ $4.0 /)$.

\begin{abstract}
Lignocellulose and starch-based raw materials are often applied in the investigations regarding biohydrogen generation using dark fermentation. Management of the arising post-fermentation broth becomes a problem. The Authors proposed sequential processes, to improve the efficiency of both hydrogen generation and by-products management carried under model conditions. During the proposed procedure, the simple sugars remaining in broth are converted into organic acids, and when these products are used as substrates for the photo fermentation process. To enhance the broth management also conditions promoting Deep Eutectic Solvents (DES) precursors synthesis are simultaneously applied. Application of Box-Behnken design allows defining of the optimal conditions for conversion to DESs precursors. During the procedure hydrogen was obtained, the concentration of hydrogen in the photo fermentation reached up to $819 \mathrm{~mL}_{\mathrm{H} 2} / \mathrm{L}_{\text {medium }} / 7 \mathrm{~d}$, depending on the broth type, i.e., when the broth was optimized for formic acid concentration. The DESs precursors were separated and engaged in DESs synthesis. To confirm the formation of the DESs, FT-IR analyses were performed. The Chemical Oxygen Demand of post-fermentation broths after dark fermentation optimized for formic acid was reduced by ca. $82 \%$. The proposed procedure can be successfully used as a method of post-fermentation broth management.
\end{abstract}

Keywords: dark fermentation; photo fermentation; hydrogen; HMF; furfural; levulinic acid; biorefining; DES; green solvents; Rhodospirillum rubrum

\section{Introduction}

Hydrogen may be generated during various biochemical reactions [1]. For example, it is an intermediate product in methane fermentation, immediately consumed by methanogenic bacteria, it may be generated via photo fermentation and microbiological electrolysis or through direct biophotolysis [2,3]. Up to date, dark hydrogen fermentation seems to be one of the most promising biological methods of hydrogen synthesis [4]. It may be carried only with the participation of anaerobic microorganisms, which convert simple sugars as the sole carbon source [5]. The main gaseous fermentation products include hydrogen and carbon dioxide and main liquid products are ethanol or organic acids (most often acetic, formic, lactic or butyric) [6]. The main issues related to dark fermentation involve raw material pretreatment, inhibitory compounds formation and fermentation broth management. To synthesize high-energy gas, it is crucial to degrade polysaccharides (of starch or lignocellulose origin) to monosaccharides with the employment of chemical, enzymatical or physicochemical methods [7]. The authors have carried research regarding the pre-treatment of polysaccharide-rich raw materials and their application in dark fermentation. Conclusions from the published results [8-10] indicate, that to increase the profits of dark fermentation, parallel research on the management of post-fermentation broth must be carried.

Lignocellulose and starch-based raw materials are often applied in the investigations regarding biohydrogen generation using dark fermentation (DF). Selected raw materials 
used in dark fermentation are mentioned in Table 1. The literature presents only a little information regarding the management of post-fermentation broths [5,11,12]. Since under real conditions, this type of waste arises, it becomes a problem due to the need for a scale-up trend of hydrogen generation. Therefore investigations regarding broth management methods development would contribute to the actual state of knowledge. The composition of DF post-fermentation broth includes substances generated during the growth of microorganisms (Table 1), the remnants of the culture medium and cell breakdown products $[13,14]$.

Table 1. List of liquid products most commonly generated during dark fermentation [3,15-18].

\begin{tabular}{|c|c|c|c|}
\hline Raw Material & Microorganism & Liquid Products & References \\
\hline Cattle wastewater $1.3 \mathrm{~g} \mathrm{COD} / \mathrm{dm} 3$ & Sewage sludge & butyric acid, acetic acid, ethanol, propionic acid & {$[3]$} \\
\hline Dairy manures $70 \mathrm{~g} / \mathrm{dm} 3$ & Clostridium sp. & $\begin{array}{l}\text { butyric acid, acetic acid, ethanol, propionic } \\
\text { acid, butanol }\end{array}$ & {$[15]$} \\
\hline Jatropha curcas-biodiesel industry residue & Mixed cultures (activated sludge) & $\begin{array}{c}\text { butyric acid, ethanol, acetic acid, propionic acid, } \\
\text { valeric acid }\end{array}$ & {$[16]$} \\
\hline Delignified wood fibers $0.1 \mathrm{~g} / \mathrm{dm} 3$ & Clostridium thermocellum ATCC 27405 & acetic acid, ethanol, formic acid & [17] \\
\hline Delignified hydrolysate of lignocellulosic biomass & Anaerobic bacteria & lactic acid, citric acid, acetic acid & [18] \\
\hline
\end{tabular}

COD_chemical oxygen demand.

To process broths possibly containing organic acids and ethanol as listed in Table 1, the remaining microorganisms and cell parts, a separation step must be carried. Removal of proteins and microbial parts requires sterilization [19]. Remnant mono sugars may be simultaneously converted into furfural (FF), 5-hydroxymethylfurfural (HMF), levulinic acid (LA) and formic acids (FA) during sterilization [20] if the environment for conversion is acidified. The precipitated residues can be further separated by centrifugation [21]. To achieve the defined goals, the thermal sterilization variant should be used, and the broth should be acidified to catalyze the conversion of residues of mono sugars into the mentioned products [22]. Since acetic acid is present in the post-dark fermentation broth, it is planned to be used as the acidic agent [23] in further processing stages, i.e., photo fermentation and biorefining.

Photo fermentation is the fermentative decomposition of organic substrates directly into hydrogen, which is caused by various photosynthetic microorganisms, including primarily purple and green anaerobic bacteria. The advantage of photo fermentation is the fact that the hydrogen produced is relatively pure (it contains up to $20 \%$ carbon dioxide) which eliminates the necessity of the energetically and time-consuming purification process of the obtained gas. For this reason, photo fermentation with the use of nitrogenase arouses considerable interest among researchers and practitioners dealing with the synthesis of biohydrogen. Under light conditions, purple non-sulfur bacteria, including Rhodobacter species [24] use organic acids such as acetate, lactate and butyrate for this purpose, and purple sulfur bacteria use reduced sulfur compounds and the product of the process is molecular hydrogen [25]. Since heterotrophic bacteria decompose organic acids into hydrogen, the DF broth seems to be an ideal substrate in photo fermentation. The photosynthetic system of green algae is more complex compared with purple bacteria. It consists of a photosystem fixed in the intracellular membrane and is not powerful enough to split water. Under anaerobic conditions, these bacteria can use simple organic acids, such as acetic acid, or even dihydrogen sulfide as an electron donor The basic enzyme responsible for the production of hydrogen is nitrogenase [26], while the transfer of electrons is possible by hydrogenase, which is responsible for the oxidation of hydrogen to water. If there is nitrogen in the environment, the primary function of nitrogenase is to convert nitrogen into ammonia [24]. In addition, oxygen is an inhibitor of nitrogenase, it deactivates the enzyme center, significantly affecting its activity [20]. The conversion of light energy induces ATP formation and hydrogen generation only in advantageous conditions [27].

The coupling of dark fermentation with mentioned processes may increase the hydrogen efficiency and decrease the COD of the remaining medium $[15,26,28]$. Considering the 
hydrogen formed during biological processes may be contaminated with $\mathrm{NH}_{3}, \mathrm{CO}_{2}, \mathrm{CH}_{4}$, $\mathrm{H}_{2} \mathrm{~S}$, a gaseous stream purification must be concerned.

To enhance the post-fermentation broth management, biorefining via a simultaneous process of residual mono sugars conversion needs to be carried. Residual glucose from starch or lignocellulose and xylose from lignocellulose may be converted into furfural, HMF and formic and levulinic acids [29]. Since the concentrations of residual mono sugars after DF are expected to be relatively low, i.e., under $0.5 \mathrm{~g} / \mathrm{L}$, the inhibitory effect of its conversion products presence is not considered to affect the photo fermentation. The products occurring in the liquid stream after photo fermentation may be however extracted and used as DESs precursors. Investigations regarding possible inhibitory effects of mentioned DESs precursors should be considered as a future research direction, as their concentration may be a significant parameter affecting the hydrogen yield during coupled processes of dark and photo fermentations.

Summarising, dark fermentation and photo fermentation should be carried as sequential processes. At first simple sugars are converted into organic acids during dark fermentation, and then these products are used as a substrate for the photo fermentation process. To enhance the broth management also conditions promoting DES precursors synthesis are simultaneously applied. To the best knowledge of the authors, results regarding the conversion of remnants of mono sugars after dark fermentation are not published in the literature. In addition, the optimization of photo fermentation medium in the presence of hydroxymethyl furfural, furfural, levulinic acid and formic acid were not investigated. Therefore, the research aims to define the optimal conditions for simultaneous hydrogen and DES precursors synthesis in model investigations.

\section{Materials and Methods}

\subsection{Analytical Methods}

- $\quad$ The mono sugars (glucose, xylose) and the HMF, FF and LA conversion product concentrations in samples were confirmed by analysis using HPLC (Merck-Hitachi, Germany) equipped with a YMC-Pack ODS-2 column $(5 \mu \mathrm{m}, 250 \times 4.6 \mathrm{~mm}, \mathrm{YMC}$, Co, Ltd. Japan, Inc. USA), refractometric detector (RID-RI Detector 2100-Knauer, Germany) and a spectrophotometric (UV-VIS-DAD) detector (L-7450-Merck-Hitachi, Germany) at $284 \mathrm{~nm}$. The samples were filtered through a syringe filter with a PA membrane with a pore diameter of $0.45 \mu \mathrm{m}$. A filtered sample of the hydrolysate in a volume of $20 \mu \mathrm{L}$ was analyzed by HPLC. The mobile phase was $1 \%$ sulfuric acid-methanol $(85: 15 \mathrm{v} / \mathrm{v})$ at a flow rate of $0.6 \mathrm{~mL} / \mathrm{min}$. The HPLC column was maintained at room temperature.

- Gaseous products of photo fermentation $\left(\mathrm{H}_{2}, \mathrm{O}_{2}\right.$ and $\left.\mathrm{CO}_{2}\right)$ were analyzed using a gas chromatograph (Autosystem XL) coupled with a thermal conductivity detector (TCD) (PerkinElmer, Waltham, MA, USA) and packed column Porapack Q 100-120 mesh, OD $3.2 \mathrm{~mm} \times 6.5 \mathrm{~m}$ (Sigma-Aldrich, Merck, Darmstadt, Germany). The oven temperature was at $60{ }^{\circ} \mathrm{C}$. In the investigations, the TurboChrom 6.1 software (PerkinElmer, Waltham, MA, USA), was used. Gas samples were analyzed after the photo fermentation, on the 10th day of bacterial growth.

- The $\mathrm{pH}$ during photo fermentation was continuously monitored during the fermentation (Arduino Microcontroller data-logger, Continuous $\mathrm{pH}$ regulative system developed at the Gdańsk University of Technology, Gdańsk, Poland). The growth of $R$. rubrum culture was monitored by measuring the OD at $\lambda=600 \mathrm{~nm}$ (optical density of culture).

- $\quad$ The protein concentration was measured using UV-VIS spectrophotometry at $750 \mathrm{~nm}$ and Folin-Ciocalteu method on Hach Lange DR 5000 apparatus [30].

\subsection{Model Photo Fermentation Broth Characterization}

The post-fermentation broth after dark fermentation of pre-treated lignocellulosic biomass includes several chemical compounds, which must undergo photo fermentation 
and biorefining during the planned research. On the other hand, the process parameters require optimization. Therefore, based on original research $[9,10,28,31,32]$, model broths were prepared. The initial dark fermentation broth was composed of a sterile minimal medium Buffered Peptone Water (Biomaxima, Gdańsk, Poland) and lignocellulosic biomass hydrolysates, as the sole carbon source for hydrogen-generating anaerobic microorganisms; i.e., Enterobacter aerogenes ATCC 13048 [10]. As an effect of fermentation, several bioproducts were found and identified, i.e., acetic acid, residual glucose and xylose and proteins present due to microorganism termination. The concentration of proteins was measured using Folin-Ciocalteu method.

To prepare model post-fermentation broths, the mentioned substances were diluted in distilled water in the concentrations given in brackets: glucose $(1 \mathrm{~g} / \mathrm{L})$; xylose $(1 \mathrm{~g} / \mathrm{L})$; Buffered Peptone Water $(5 \mathrm{~g} / \mathrm{L})$; BSA protein $(0.2 \mathrm{~g} / \mathrm{L})$; ethanol $(0.2 \mathrm{~g} / \mathrm{L})$; acetic acid $(2 \%)$.

Residual glucose and xylose in post-dark fermentation broth may be converted into furfural, HMF and formic and levulinic acids. Due to literature research and concerning the composition of post-fermentative broth, the authors decided to use acetic acid and temperature as the agents enabling the conversion over time. Since the process of conversion requires optimization, the authors defined statistically important variables and carried research applying the Box-Behnken design (BBD). In Table 2, the statistically important variables and the range of experiments were defined.

Table 2. The border conditions of the statistically significant variables.

\begin{tabular}{cccccc}
\hline Variable & \multirow{2}{*}{ Unit } & Symbol & $\mathbf{- 1}$ & $\mathbf{0}$ & $\mathbf{1}$ \\
\hline temperature & ${ }^{\circ} \mathrm{C}$ & $\mathrm{X} 1$ & 60 & 75 & 90 \\
time & $\mathrm{h}$ & $\mathrm{X} 2$ & 2 & 24 & 46 \\
acetic acid concentration & $\%$ & $\mathrm{X} 3$ & 10 & 35 & 60 \\
\hline
\end{tabular}

The response surface methodology (RSM) was used to determine the optimal conditions of residual sugar conversion, in the range defined in Table 2. Further research was carried out using the Box-Behnken design. The plan includes 15 experiments with different levels of three variables (Table 3) used to determine the influence of each of the variable parameters and their mutual interactions on the furfural, HMF, levulinic acid and formic acid concentrations.

Table 3. Box Behnken experimental design for the residual mono sugars conversion process.

\begin{tabular}{|c|c|c|c|c|c|c|c|c|c|}
\hline \multirow{3}{*}{ Exp. No. } & \multirow{3}{*}{$\mathrm{X} 1$} & \multirow{3}{*}{$\mathrm{X} 2$} & \multirow{3}{*}{$\mathrm{X} 3$} & \multicolumn{2}{|c|}{ Feed Residues } & \multicolumn{4}{|c|}{ DES Precursors Concentration } \\
\hline & & & & Glu, Xyl & AA & FA & LA & HMF & FF \\
\hline & & & & $\mathrm{g} / \mathrm{L}$ & $\mathrm{g} / \mathrm{L}$ & $\mathrm{g} / \mathrm{L}$ & $\mathrm{g} / \mathrm{L}$ & $g / L$ & $\mathrm{~g} / \mathrm{L}$ \\
\hline 1. & 60 & 2 & 35 & 41.17 & 271.210 & 11.210 & n.d & 0.001 & 0.001 \\
\hline 2. & 90 & 2 & 35 & 21.97 & 330.730 & 112.260 & n.d & 0.001 & 0.015 \\
\hline 3. & 60 & 46 & 35 & 42.85 & 281.230 & 41.360 & n.d & n.d. & 0.005 \\
\hline 4. & 90 & 46 & 35 & 17.54 & 330.730 & 19.590 & 0.428 & 0.102 & 0.690 \\
\hline 5. & 60 & 24 & 10 & 24.96 & 306.880 & 0.066 & n.d. & 0.000 & 0.001 \\
\hline 6. & 90 & 24 & 10 & 19.41 & 117.850 & 4.880 & 0.561 & 0.029 & 0.229 \\
\hline 7. & 60 & 24 & 60 & 18.15 & 536.720 & 280.680 & n.d. & 0.001 & 0.002 \\
\hline 8. & 90 & 24 & 60 & 11.91 & 271.210 & 11.210 & 1.553 & 0.031 & n.d. \\
\hline 9. & 75 & 2 & 10 & 10.13 & 102.630 & 117.030 & n.d. & 0.001 & 0.001 \\
\hline 10. & 75 & 46 & 10 & 11.44 & 115.650 & 1.610 & 0.112 & 0.003 & 0.032 \\
\hline 11. & 75 & 2 & 60 & 11.52 & 420.097 & 137.290 & n.d. & n.d. & n.d. \\
\hline 12. & 75 & 46 & 60 & 11.97 & 394.860 & 153.420 & n.d. & 0.004 & 0.035 \\
\hline 13. & 75 & 24 & 35 & 41.17 & 323.630 & 105.350 & n.d. & 0.001 & 0.017 \\
\hline 14. & 75 & 24 & 35 & 21.97 & 340.570 & 114.380 & n.d. & 0.001 & 0.018 \\
\hline 15. & 75 & 24 & 35 & 42.85 & 332.580 & 83.380 & n.d. & 0.001 & 0.018 \\
\hline
\end{tabular}

LOD: 2 g/L (Glu, Xyl); 10 g/L (AA); 0.03 g/L (FA); 0.0005 g/L (FF); 0.1 mg/L (LA); 0.0005 g/L (HMF); n.d.—not detected; SD: \pm 0.46 (Glu, Xyl); \pm 5.96 (AA); \pm 1.59 (FA); \pm 0.001 (FF); \pm 0.003 (LA); \pm 0.0002 (HMF); X1—conversion temperature, ${ }^{\circ} \mathrm{C} ; \mathrm{X} 2$ - conversion time, $\mathrm{h} ; \mathrm{X} 3$ - acetic acid concentration, $\%(v / v)$-for coding level please refer to Table 2. 
Matching the dependences of the variables with the response values, a second-order polynomial Equation presented in the general form was applied according to [10].

During the Box-Behnken optimization, $10 \mathrm{~mL}$ of model broth solution was used for variables defined by BBD. The solution was incubated in a bed shaker in temperature over time defined by the sample number. After the conversion, the solution was centrifuged and filtered through the Buchner funnel to separate the solid fraction, containing mainly protein remnants. The solid residue may be directed to biomass gasification, thus is not an object of this paper. The liquid is directed to HPLC analysis for glucose, xylose.

Furfural, 5-HMF, levulinic acid, formic acid and acetic acid concentration determination.

\subsection{Photo Fermentation}

Photo fermentations were carried using model post-fermentation broths from dark fermentation, which were obtained based on parameters determined by BBD. The regression equations and optimal values for DES precursors obtained via RSM analysis are presented in Table 4. A list of the type of broth, process parameters and the obtained amounts of post-fermentation gas and concentration of generated hydrogen is presented in Table 5.

Rhodospirillum rubrum is a frequently studied species [31], exhibiting unique nitrogenase activity, reducing both molecular nitrogen and protons to molecular hydrogen. In addition to the ability to bind carbon dioxide, it can bind nitrogen. It contains both Fe-Mo(iron-molybdenum) and Fe-nitrogenase. The microorganisms that synthesize biohydrogen in the photo fermentation process with the use of hydrogenase also include purple sulfur bacteria, which are strict anaerobes, i.e., Allochromatium vinosum, Chlorobium vibloroforme, Chloroflexus aurantiacus, Desulfuromonas acetoxidans and Thiocapsa roseopersicina [32]. The electromagnetic radiation wavelenght absorbed by photofermentation bacteria is in the range from 400 to $950 \mathrm{~nm}$ [33]. To increase the efficiency and economy of biohydrogen production by this method, biotechnologists currently use a genetic modification of microorganisms, metabolic engineering and cell immobilization [34].

Photo fermentations were carried out in a batch system in glass reactors with a working capacity of $1 \mathrm{~L}$. Rhodospirillum rubrum was used in the process, and the applied light intensity was equal to $5 \mathrm{klx}$ (300 W, Ultra Vitalux lamp). Bacterial propagation was performed on van Niel medium and cultures were carried out after inoculation in a liquid medium containing $80 \%$ of the broth prepared according to the data in Table 5 and $20 \%$ of the inoculum. The broths were inoculated after the $\mathrm{pH}$ was adjusted to 4.5 with acetic acid. Before inoculation, the broth was deoxygenated by purging with an inert gas (nitrogen, purity N5) for $20 \mathrm{~min}$. The fermentation gas was collected in Tedlar bags (3 L), and its composition and quantity were determined on the 10th day of photo fermentation. After the end of the process, the broth was heated to $60{ }^{\circ} \mathrm{C}$ for $5 \mathrm{~min}$. In this way, the proteins released during the breakdown of bacterial cells were denatured. Both denatured proteins and cellular debris were centrifuged, the pellet was directed for gasification and the supernatant for directed for biorefining. Table 5.

The protein concentration in the supernatant after photo fermentation is presented in

\subsection{DES Separation}

Inhibitors of fermentation including HMF, FF, LA and FA were removed from the fermentation broth by the new in-situ DES formation method. For this purpose, a substance that acts as a hydrogen bond donor (HBD) was added to the fermentation broth. To select the most favorable HBD, preliminary separation tests of inhibitors were carried out on a post photo fermentation model broth. The model broth was prepared by dissolving FF $(1 \mathrm{~mL}), \mathrm{HMF}(0.0578 \mathrm{~g}), \mathrm{LA}(1 \mathrm{~mL}), \mathrm{FA}(1 \mathrm{~mL})$ in water $(200 \mathrm{~mL})$. HBD including carvone (LC), thymol (Th), eucalyptol (E) and menthol (M), were tested. After adding $0.5 \mathrm{~g}$ of $\mathrm{HBD}$ to $20 \mathrm{~mL}$ of the fermentation broth, the solution was stirred with a magnetic stirrer for $30 \mathrm{~min}$ at $80{ }^{\circ} \mathrm{C}$. Then the solution was centrifuged for $5 \mathrm{~min}$ at a rotation speed of $5000 \mathrm{rpm}$. The DES phase that was formed above the surface of the fermentation broth 
was transferred to the separate vial. The efficiency of the separation process was examined using the liquid chromatography method. The aqueous phase was analyzed using a HPLC system coupled with a UV-VIS-DAD detector at $284 \mathrm{~nm}$. The HPLC conditions were used the same as for the mono sugars conversion process.

\section{Results and Discussion}

\subsection{Design of Experiment}

The overall concept of the paper is to optimize the process of post-fermentative broth management and improve the efficiency of hydrogen generation with the employment of photo fermentation as a sequential step after dark fermentation. The stages involved in the procedure are presented in Figure 1.

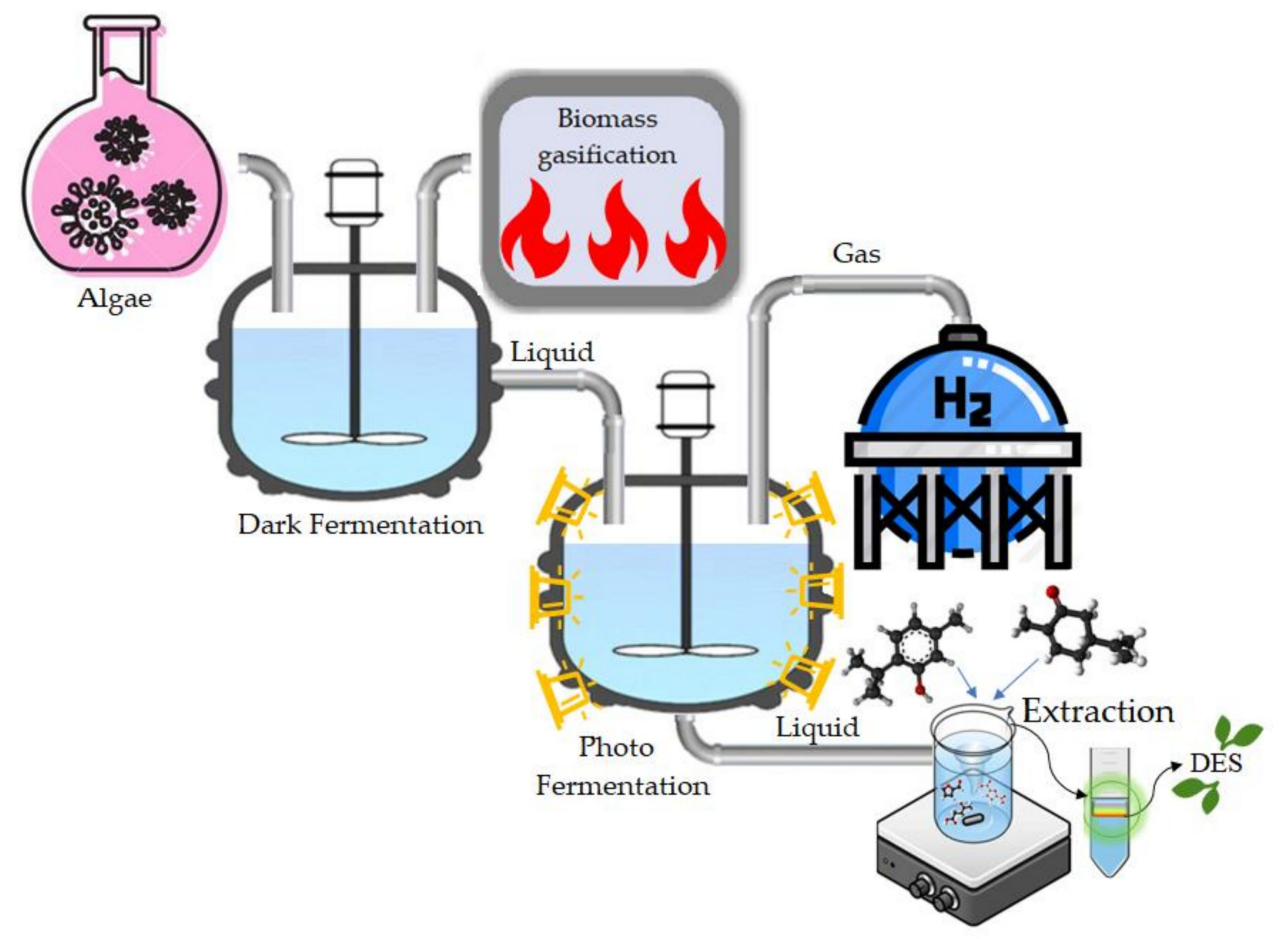

Figure 1. Design of experiment.

The mono sugars are used as the sole carbon source by DF microorganisms. As an effect of their metabolism, by-products are formed. Acetic acid is a compound that, according to our previous research and the literature, is formed in the highest concentrations. Due to the acetic acid formation the $\mathrm{pH}$ decreases and the ionic strength increases. At some point, even though the $\mathrm{pH}$ is controlled, the broth conditions are no longer optimal for DF microorganisms and therefore even though mono sugars remnants are still available, the DF microorganism does not generate hydrogen. At this point, the post-DF broth contains acetic acid, which may be used by photofermentation algae as the sole carbon source. To separate the DF microbial parts and proteins, the post-DF broth needs to be clarified. The Authors applied heating and centrifugation for this purpose. As increased temperature and low $\mathrm{pH}$ promote the secondary chemical transformation of mono sugars, to substances that may be considered as DESs precursors, the Authors carried research in this niche. The inhibitory effect of these substances may occur even in low concentrations and should be considered as an object for further research. Acetic acids formation decreases the hydrogen yield in DF, however, the coupling of this process with subsequent photo fermentation allows increasing its efficiency.

The post- fermentative broth from dark fermentation is directed to chemical conversion. The authors expect to obtain deep eutectic solvents precursors and to optimize the conversion using Box Behnken design. The application of acetic acid as the chemical agent 
catalyzing the conversion and increased temperature over time will affect the denaturation of proteins and precipitation of dark fermentation microorganisms remnant. Therefore, after the conversion, solids and liquids must be separated via centrifugation. The solid stream may be directed to biomass gasification, while the liquids are to be the feed, in photo fermentation.

As a result of photo fermentation, hydrogen is expected to be obtained. The liquid remainings leftover photo fermentation is planned to be directed to extraction, to separate the former synthesised deep eutectic solvents precursors.

\subsection{Analysis of Model Post-Fermentation Broth}

To determine the effects of the temperature, time and acetic acid (AA) concentration on the efficiency of residual mono sugars (glucose (Glu) and xylose (Xyl)) conversion to DES precursors, the final concentrations of FF, HMF, FA and LA were determined using HPLC (Table 3). The range and coding level of variables introduced in the Box-Behnken design are given in Table 2.

Initial sugar concentration applied during the investigations in Box Behnken design (Table 3) is equal to $50 \mathrm{~g} / \mathrm{L}$ (glucose $/$ xylose $=1: 1 \mathrm{~m} / \mathrm{m}$ ). It can be observed, that in the case of all carried experiments, the concentration of mono sugars decreases during the experiment. It can also be observed, that the decrease is higher when the applied temperature is higher. In the range of the samples processed in the same value of temperature, the time of processing and the applied acetic acid concentration seem not to have any significant effect on the mono sugars concentration decrease. However, depending on time and acetic acid concentration, different substances are formed as DES precursors. Therefore, it is determined that the selection of variables and their values may affect the ongoing conversion and permits the planning of the main product of conversion in the given range. No trend regarding the remaining acetic acid after the conversion was observed. However, data informing about the acetic acid concentration after the conversion process are crucial for photo fermentation feed preparation.

\subsection{Optimization of the Residual Mono Sugars Conversion Process}

The concentration of DES precursors strongly depends on the experiment profile. The dependence of the results on a certain type of processing is given in Table 4 . Exemplary response surface plots are presented in Figure 2. The precise values of obtained concentrations are provided in Table 3.

Table 4. The regression equations and optimal values for DES precursors obtained via RSM analysis.

\begin{tabular}{|c|c|c|c|}
\hline Modeled Substance & Regression Equation & Determination Coefficient & Optimal Values \\
\hline LA & $\begin{array}{l}\mathrm{C}_{\mathrm{LA}}=8.26-0.212 \mathrm{X} 1-0.0691 \mathrm{X} 3+0.001349 \mathrm{X} 1 * \mathrm{X} 1-0.000406 \\
\mathrm{X} 2 * \mathrm{X} 2+0.000359 \mathrm{X} 3 * \mathrm{X} 3+0.000324 \mathrm{X} 1 * \mathrm{X} 2+0.000661 \mathrm{X} 1 * \mathrm{X} 3\end{array}$ & 0.781 & $\begin{array}{l}\mathrm{X} 1=90^{\circ} \mathrm{C} \\
\mathrm{X} 2=32.2 \mathrm{~h} \\
\mathrm{X} 3=60 \%\end{array}$ \\
\hline HMF & $\begin{array}{c}\mathrm{C}_{\mathrm{HMF}}=0.498-0.01320 \mathrm{X} 1-0.00576 \mathrm{X} 2+0.00053 \mathrm{X} 3+0.000084 \\
\mathrm{X} 1 * \mathrm{X} 1+0.000012 \mathrm{X} 2 * \mathrm{X} 2\end{array}$ & 0.864 & $\begin{array}{l}\mathrm{X} 1=90^{\circ} \mathrm{C} \\
\mathrm{X} 2=46 \mathrm{~h} \\
\mathrm{X} 3=37.2 \%\end{array}$ \\
\hline FF & $\begin{array}{c}\mathrm{C}_{\mathrm{FF}}=2.36-0.0663 \mathrm{X} 1-0.0399 \mathrm{X} 2+0.0171 \mathrm{X} 3+0.000448 \mathrm{X} 1 * \mathrm{X} 1+ \\
0.000123 \mathrm{X} 2 * \mathrm{X} 2+0.000509 \mathrm{X} 1 * \mathrm{X} 2\end{array}$ & 0.821 & $\begin{aligned} \mathrm{X} 1 & =90^{\circ} \mathrm{C} \\
\mathrm{X} 2 & =46 \mathrm{~h} \\
\mathrm{X} 3 & =17.57 \%\end{aligned}$ \\
\hline FA & $\begin{array}{l}\mathrm{C}_{\mathrm{FA}}=-1464+34.8 \mathrm{X} 1+5.30 \mathrm{X} 2+12.93 \mathrm{X} 3-0.185 \mathrm{X} 1 * \mathrm{X} 1-0.0277 \\
\mathrm{X} 2 * \mathrm{X} 2+0.0235 \mathrm{X} 3 * \mathrm{X} 3-0.0930 \mathrm{X} 1 * \mathrm{X} 2-0.1829 \mathrm{X} 1 * \mathrm{X} 3+0.0598 \mathrm{X} 2 * \mathrm{X} 3\end{array}$ & 0.801 & $\begin{array}{l}\mathrm{X} 1=60^{\circ} \mathrm{C} \\
\mathrm{X} 2=46 \mathrm{~h} \\
\mathrm{X} 3=60 \%\end{array}$ \\
\hline
\end{tabular}

$p$-value $\leq 0.05$. 


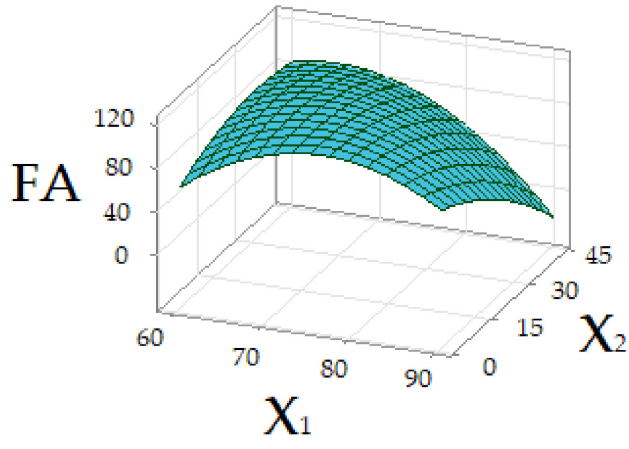

(a)

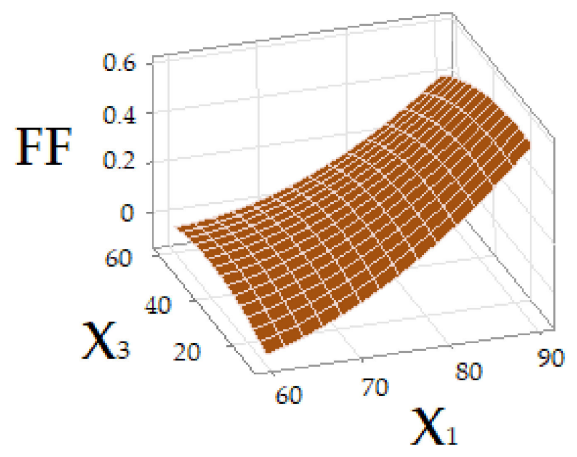

(c)

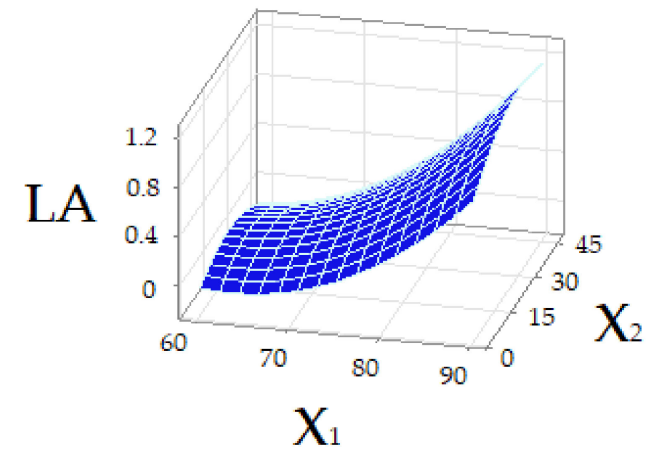

(b)

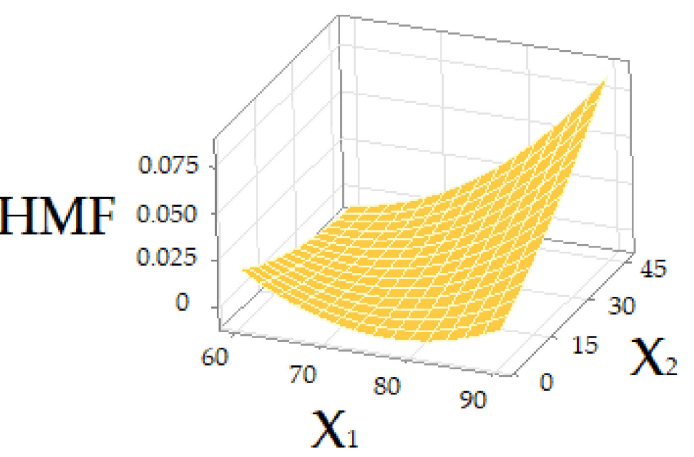

(d)

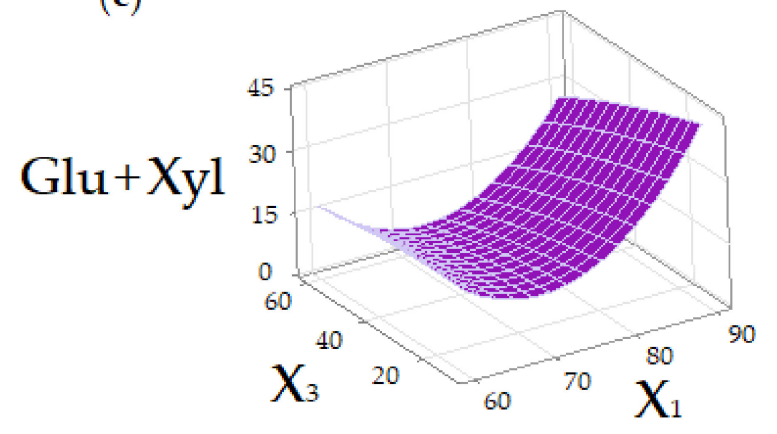

(e)

Figure 2. Response surface plots. (a) Surface plot of FA concentrations in dependence of $\mathrm{X} 1, \mathrm{X} 2$ for hold value of concentration $\mathrm{X} 3=35 \%$; (b) Surface plot of LA concentrations in dependence of X1, X2 for hold value of concentration $X 3=60 \%$; (c) Surface plot of FF concentrations in dependence of X1, X3 for hold value of concentration X3 $=60 \%$; (d) Surface plot of HMF concentrations in dependence of X1, X2 for hold value of time X2 $=46 \mathrm{~h}$; (e) Surface plot of glucose and xylose concentrations in dependence of $\mathrm{X} 1, \mathrm{X} 3$ for hold value of time $\mathrm{X} 2=24 \mathrm{~h}$.

After carrying out the experimental conversion of glucose and xylose with acetic acid according to Table 3, it was found that, as expected, it is possible to obtain the following conversion products: FF, HMF, LA, FA. The conditions of the process lead to the formation of specific products, and thus, it seems beneficial from the point of view of the process to be selected in such a way as to obtain a specific product. As there is some conflict of interest from the point of view of the subsequent steps, i.e., biorefining and photo fermentation, two approaches should be considered. To obtain a solution of substances that can be used as sole carbon sources for photo-fermenting microorganisms, FA should be the dominant product. When considering the parameters of the model developed based on BBD, in this situation the highest concentration of acid tested, i.e., $60 \%$ AA, should be used. The formation of FA is also favored by the maximum extension of the process, up to $46 \mathrm{~h}$, and 
the use of the lowest temperature tested, i.e., $60^{\circ} \mathrm{C}$. If the most desirable conversion product were to become LA, then using high temperature, i.e., $90^{\circ} \mathrm{C}$ and AA at a concentration of $60 \%$, the optimum concentration of this product can be obtained within $32.2 \mathrm{~h}$.

Both LA and FA are secondary products of transformation. Initially, FF and HMF are formed by conversion from xylose and glucose. To minimize the decomposition of these original substances, the process should be controlled by selecting the appropriate concentration of acetic acid. It was found that at the highest of the tested temperatures, i.e., $90{ }^{\circ} \mathrm{C}$ and the maximum duration of the process, i.e., $46 \mathrm{~h}$, furfural can be obtained as the main conversion product using an acid concentration of $17.57 \%$ and $\mathrm{HMF}$ using acetic acid with a concentration at $37.2 \%$. This type of knowledge allows you to control the conversion process. If in the course of a further experiment it turns out that the obtained concentrations of HMF and FF are inhibitory for photo fermentation microorganisms, it will be possible to select appropriate conditions for the conversion process, so that the photo fermentation substrates, i.e., FA become the leading products of the process. At the same time, it will lower the concentration of inhibitors. Exemplary surface plots presenting the course of conversion are presented in Figure 2.

\subsection{Photo Fermentation Course Analysis}

Photo fermentations were carried using model post-fermentation broths from dark fermentation, obtained after conversion obtained based on parameters determined by BBD. A list of the type of broth, process parameters and the obtained amounts of post-fermentation gas and concentration of generated hydrogen is presented in Table 5. Fermentation broths obtained during conversion under conditions promoting FA, HMF and FF synthesis allowed to obtain hydrogen as one of the photo fermentation products. The highest hydrogen concentration and the gas amount were obtained for the broth composed of the highest concentrations of organic acids, i.e., acetic acid and FA. It was also found that the inhibitory effect of HMF and FF does not correspond with the photo fermentation microorganisms growth. Only in the presence of levulinic acid, hydrogen did not occur. The determination of LA inhibitory concentration may be an object of further research, as LA is also present in other broths, however in lower concentrations and does not cause an inhibitory effect.

As a result of the consumption of sole carbon sources, i.e., organic acids and the precipitation of protein and remnants of microorganisms present in the medium, COD in the medium decreased from $6253 \pm 54 \mathrm{mg} \mathrm{O}_{2} / \mathrm{L}$ to $1125 \pm 71 \mathrm{mg} \mathrm{O} / \mathrm{L}$ in FA broth type. The obtained COD value is still high, therefore further research on DES precursors extraction is carried.

Table 5. The comparison of hydrogen generation yield for different types of post dark fermentation model broths obtained with the application of conversion parameters obtained during optimization via response surface methodology.

\begin{tabular}{|c|c|c|c|c|}
\hline Broth Type & $\begin{array}{l}\text { Pre-Treatment } \\
\text { Parameters }\end{array}$ & $\begin{array}{l}\text { Gas Amount, } \\
\mathrm{L} / \mathrm{L}_{\text {medium }}\end{array}$ & $\begin{array}{l}\text { Hydrogen Concentration } \\
\left(\mathrm{L}_{\mathrm{H} 2} / \mathrm{L}_{\text {medium }} / 7 \mathrm{~d}\right)\end{array}$ & $\begin{array}{l}\text { Final Protein Concentration, } \\
\mathrm{mg} / \mathrm{L}\end{array}$ \\
\hline FA & $\begin{array}{l}\mathrm{X} 1=60{ }^{\circ} \mathrm{C} \\
\mathrm{X} 2=46 \mathrm{~h} \\
\mathrm{X} 3=60 \%\end{array}$ & $2.048 \pm 0.050$ & $0.819 \pm 0.002$ & $0.008 \pm 0.003$ \\
\hline LA & $\begin{array}{c}\mathrm{X} 1=90^{\circ} \mathrm{C} \\
\mathrm{X} 2=32.2 \mathrm{~h} \\
\mathrm{X} 3=60 \%\end{array}$ & $0.115 \pm 0.015$ & n.d. & $0.011 \pm 0.002$ \\
\hline HMF & $\begin{array}{c}\mathrm{X} 1=90^{\circ} \mathrm{C} \\
\mathrm{X} 2=46 \mathrm{~h} \\
\mathrm{X} 3=37.2 \%\end{array}$ & $1.847 \pm 0.120$ & $0.702 \pm 0.010$ & $0.007 \pm 0.001$ \\
\hline $\mathrm{FF}$ & $\begin{array}{c}\mathrm{X} 1=90{ }^{\circ} \mathrm{C} \\
\mathrm{X} 2=46 \mathrm{~h} \\
\mathrm{X} 3=17.57 \%\end{array}$ & $1.789 \pm 0.111$ & $0.612 \pm 0.002$ & $0.012 \pm 0.003$ \\
\hline
\end{tabular}




\subsection{Biorefining-DES Separation}

Currently, there are many well-known methods of purifying biogas that vary in their functioning mechanism, i.e., physical and chemical absorption, cryogenic separation, pressure swing adsorption, and membrane separation [35]. Methods based on the use of physical absorption show high efficiency of the volatile organic and inorganic compound removal from the gas phase using appropriately selected absorbents. Physical absorption includes different types of absorbents such as water, organic compounds and oils. In recent years, following the principles of green chemical and process engineering and green chemistry, classic solvents have been replaced by new generation green solvents, considering mainly deep eutectic solvents (DESs) $[36,37]$.

To the simultaneous removal of HMF, FF, FA and LA that inhibit the possibility of biohydrogen generation, deep eutectic solvents were prepared. Typically, DESs are synthesized by mixing two pure chemicals, in which one compound acting as a donor (HBD), and the other acting as a hydrogen bond acceptor (HBA) [38,39]. In these studies, a less frequently used in-situ method was applied [40]. Only one component (HBA or HBD) was added to a solution that contains DES precursors. The combination of both substances creates strong hydrogen bonds and forms a stable eutectic mixture. The solution was mixed, then centrifuged and transferred to a separate vessel. All precursors have active oxygen atoms in their structures, therefore HBD compounds should be added to the solution. When selecting HBD, several parameters were taken into account:

- hydrophobic to form a water-insoluble eutectic mixture;

- HBD must form stable eutectic mixtures with DES precursors;

- $\quad$ selectively bind to DES precursors;

- the DES formed should have a lower density than that of water for easier separation.

Therefore, the preliminary separation tests of DES precursors, such as HMF, FF, LA and FA were carried out on a model post photo fermentation broth. For this purpose compounds belonging to the terpenes group have been tested, i.e., L-Carvone (LC), thymol (Thy), eucalyptol (E) and menthol (M). In the studies, $0.5 \mathrm{~g}$ of terpenes were added to separate vials containing $0.5 \% w / w$ of individual DES precursors. The formed DES liquid phase was then taken and subjected to FT-IR analysis. Additionally, the loss of DES precursor from the water phase was checked. The obtained results indicate that no DES formation is observed upon the addition of terpenes to the process. This is most likely since among the analyzed precursors FA is the most soluble in water. The hydrogen bonds between FA and water are strong enough to prevent the formation of new competing hydrogen bonds between FA and terpenes. For the remaining DES precursors, the formation of a hydrophobic DES phase above the water surface was observed after the addition of terpenes. Figure 3 indicates that FF is the precursor that binds most readily to terpenes, in particular thymol and menthol. This is due to the specific structures of FF, and terpenes. FF has two active sites (-CHO and -O-) in its structure, playing the role of HBA. In turn, both menthol and thymol have an active hydroxyl group $(-\mathrm{OH})$ in their structures, which can form strong hydrogen bonds with the oxygen from the FF. The other tested terpenes, i.e., eucalyptol and carvone, have a ketone group $(=\mathrm{O})$ in their structures, which prevents the formation of DESs with FF. The partial removal of FF from the aqueous solution is most likely due to a mass transfer from one solution to another (LC and $E$ which are liquids at room temperature). Both HMF and LA have an additional group (-COOH or $-\mathrm{OH})$ that can act as a hydrogen bond donor. HMF showed a similar ability to form eutectic mixtures with the same terpenes as FF. LA most effectively attached to menthol, creating a hydrogen bond between the ketone group and the hydroxyl group of a terpene. A slightly lower degree of LA removal from the aqueous solution was observed for eucalyptol, which can form hydrogen bonds with the - $\mathrm{COOH}$ group. 


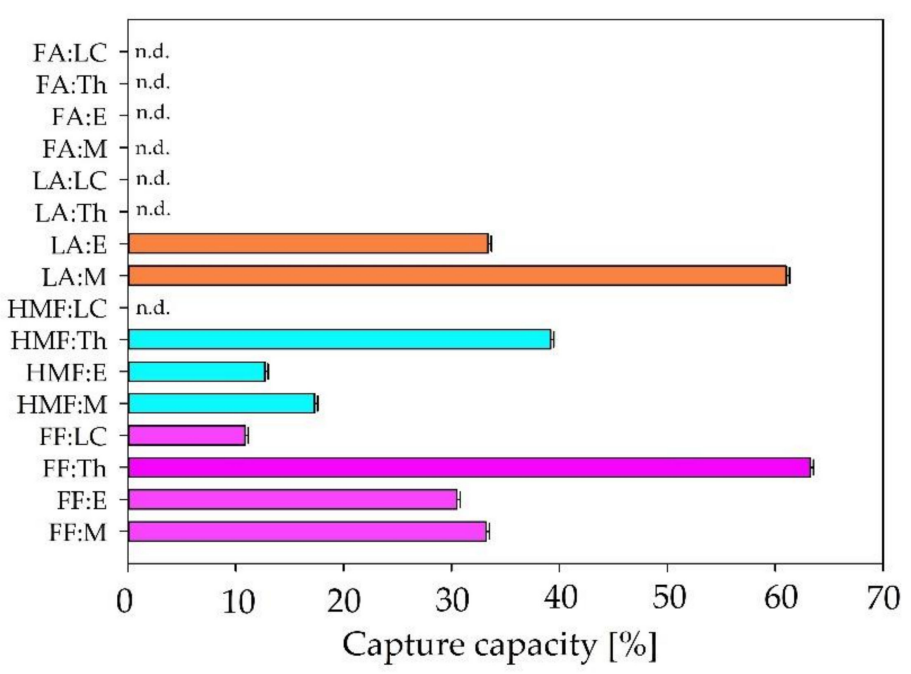

(a)

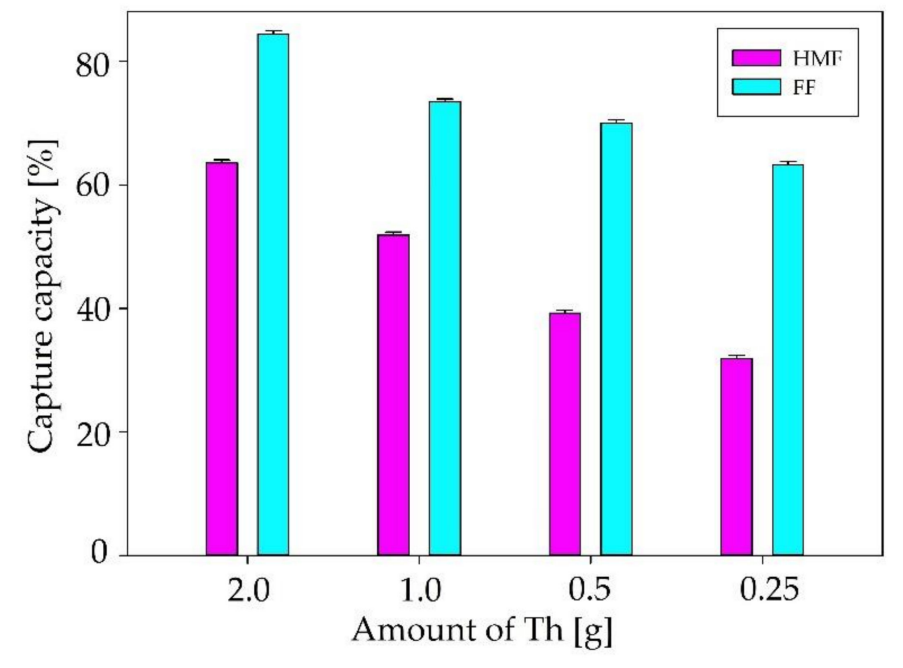

(b)

Figure 3. (a) Selection of the appropriate HBD for the selective removal of FA, LA, HMF and FF from the model fermentation broth and simultaneous formation of DES (b) Optimization of the amount of HBD used for effective removal of HMF, FF from the model fermentation broth and simultaneous formation of DES.

Th was selected for further optimization, in which the influence of the amount of added thymol in the range $0.25-2.0 \mathrm{~g}$ on the FF and HMF recovery process was examined. The obtained results (Figure $3 \mathrm{~b}$ ) indicate that as the amount of added thymol increases, the recovery of precursors DES (FF and HMF) from the model post-photo fermentation broth was increased. This is since increasing the amount of added thymol increases the number of active groups that can attach DES precursors

FT-IR spectrums describing the optimization of the kind of HBD used for effective removal off, HMF, LA and FA from the model fermentation broth and simultaneous formation of DES were presented in Supplementary Materials Figures S1-S4, respectively.

To confirm the formation of the DESs, FT-IR analyses were performed. From all of the obtained FT-IR spectra, only the spectra of DES composed on FF: Th and HMF: Th changes in spectral shifts are visible. In Figure 4 the band corresponding to the hydroxyl group $(-\mathrm{OH})$ from $\mathrm{Th}$, shifts towards lower wavenumber values in DES can be observed.

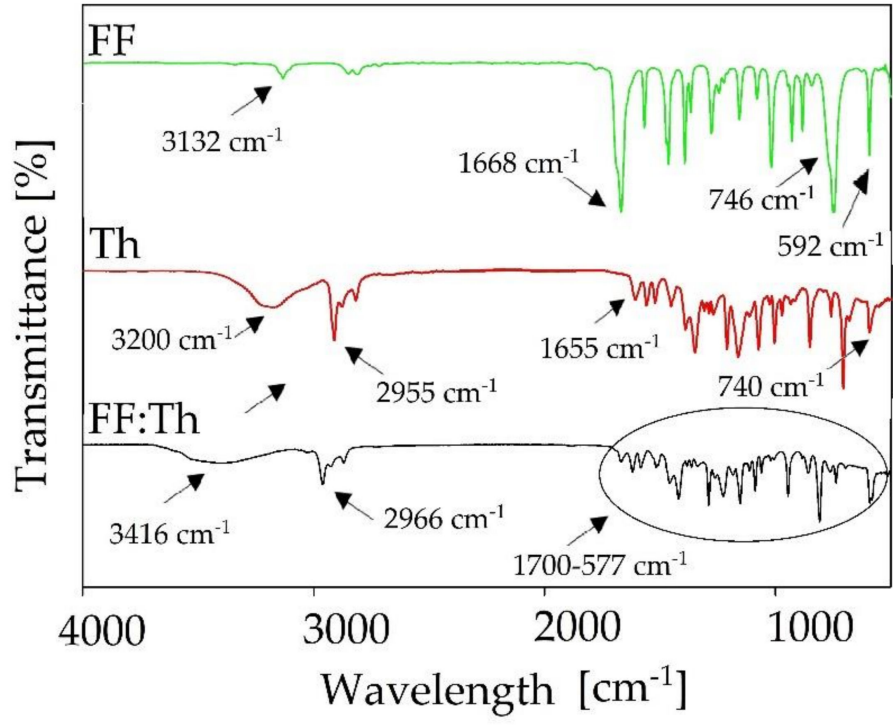

(a)

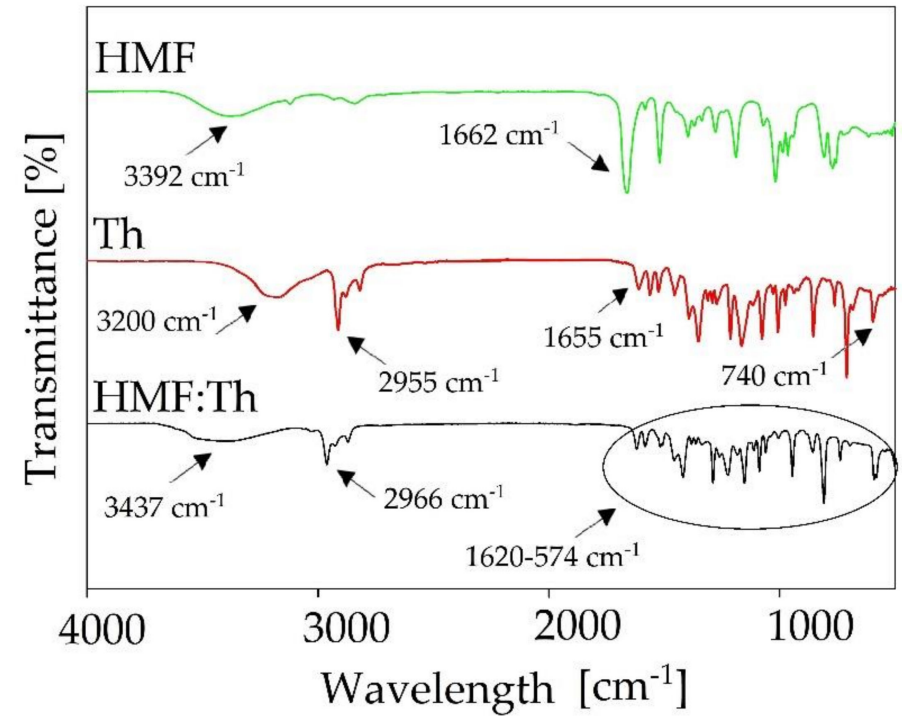

(b)

Figure 4. FT-IR spectrums from optimization of the kind of HBD used for effective removal of FF (a) and HMF (b) from the model fermentation broth and simultaneous formation of DES. 
This indicates the formation of hydrogen bonds between Th and FF, and HMF. For the remaining DES based on FA, LA no shifts were observed which confirms that LC, Th, E, M did not form DESs (Figures S1-S4). Additionally, in the FT-IR spectrum in the $1600-570 \mathrm{~cm}^{-1}$ range thymol characteristic bands (the $\mathrm{C}=\mathrm{C}$ stretching of the benzene ring, single bond - $\mathrm{OH}$ in-plane bending vibration, $\mathrm{C}-\mathrm{O}$ stretching in phenol, the out-of-plane aromatic $\mathrm{C}-\mathrm{H}$ bending) are visible in the new DESs. All identified functional groups have confirmed the formation of DES.

Additionally, to determine the influence of the amount of Th added on DES formation was performed. In the FT-IR spectra of DES, it can be observed that increasing Th amount causes the decreased intensity of the $\mathrm{C}=\mathrm{C}$ stretching bands of a benzene ring, and the outof-plane band aromatic C-H bending in the range $1671 \mathrm{~cm}^{-1}$ and $763 \mathrm{~cm}^{-1}$, respectively (Figure 5c). In the FT-IR spectra for DES-based on HMF: Th, increasing the amount of HBD causes no visible changes in the spectrum (Figure 6). It may be assumed, the change in amount does not affect the structure of FT-IR DES based on HMF: Th.

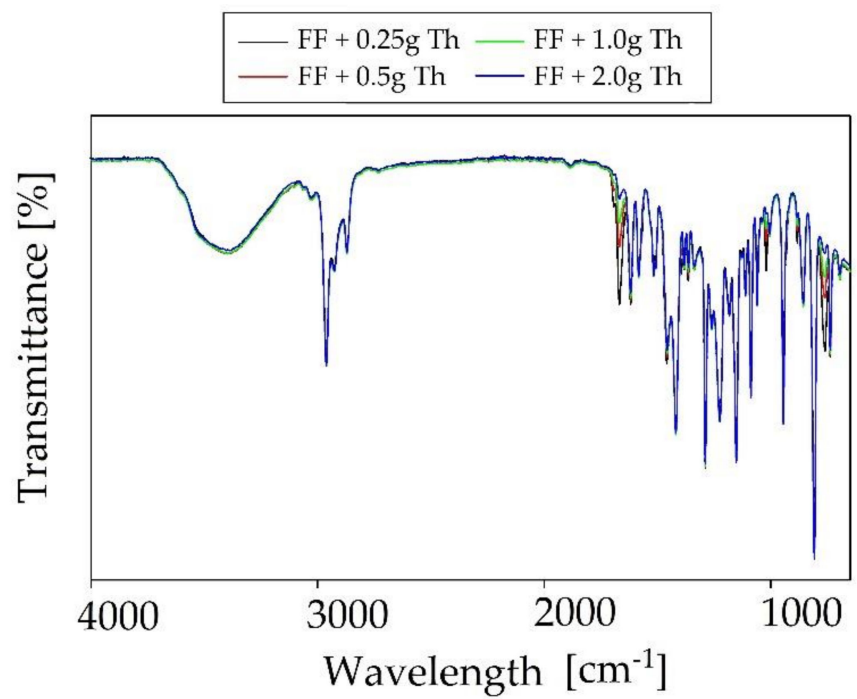

(a)

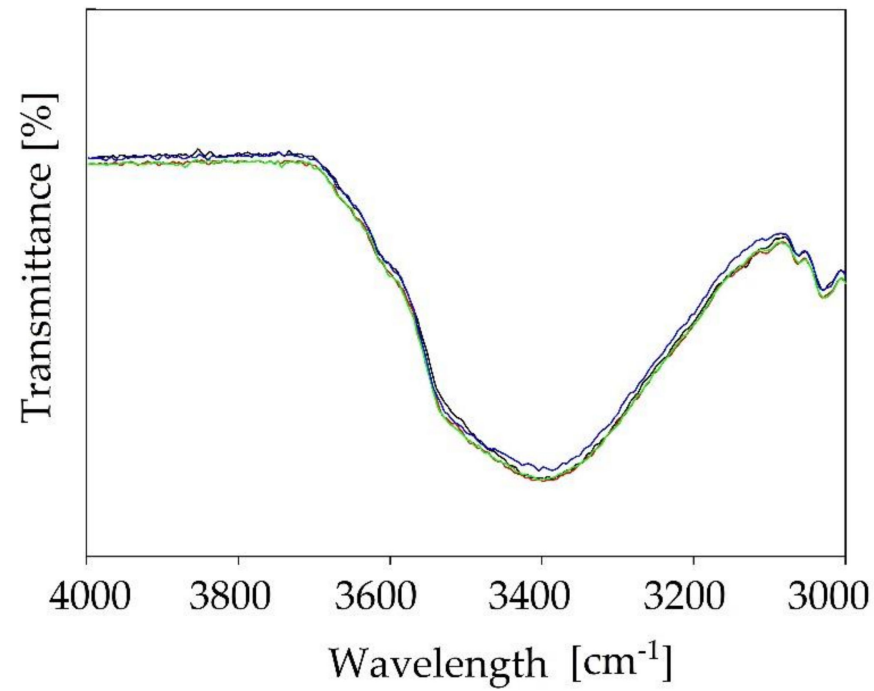

(b)

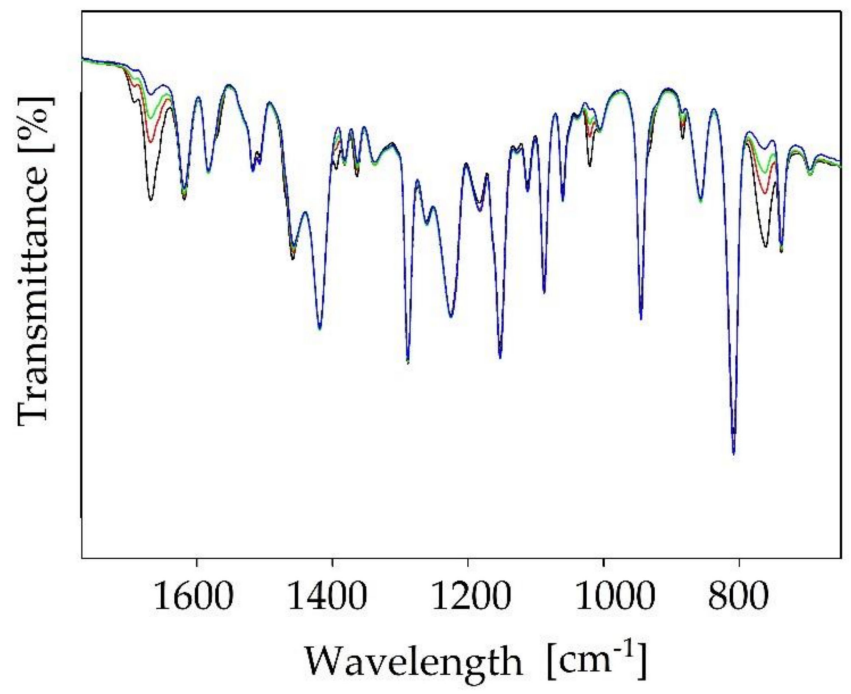

(c)

Figure 5. FT-IR spectrums from optimization of the amount of thymol (Th) to effective removal of FF from the model fermentation broth and simultaneous formation of DES; (a) all spectrum; (b) zoom spectrum at 4000-3000 cm ; $^{-1}$ (c) zoom spectrum at $1650-850 \mathrm{~cm}^{-1}$. 


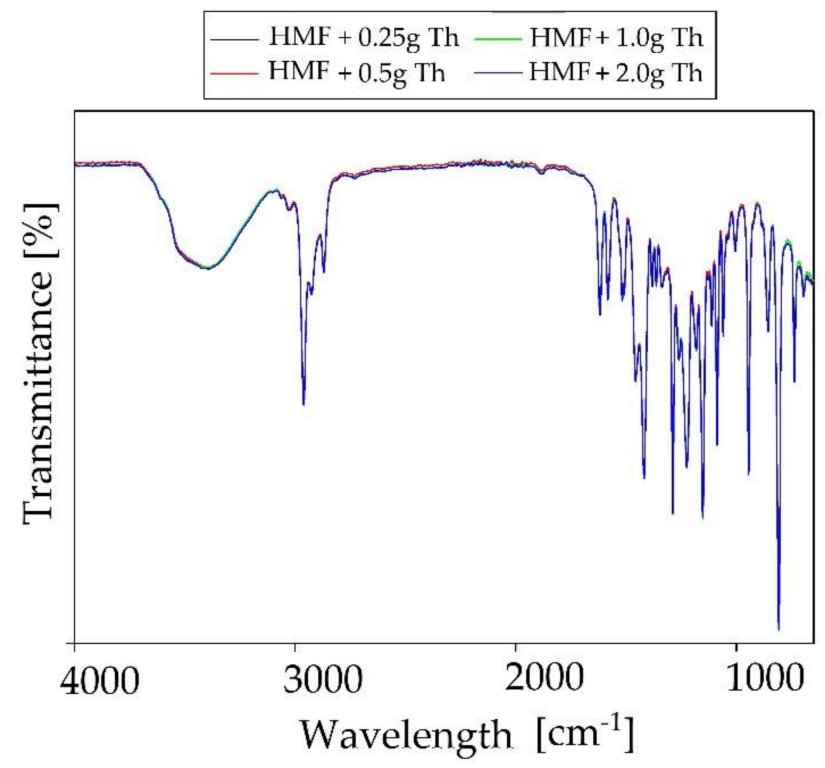

(a)

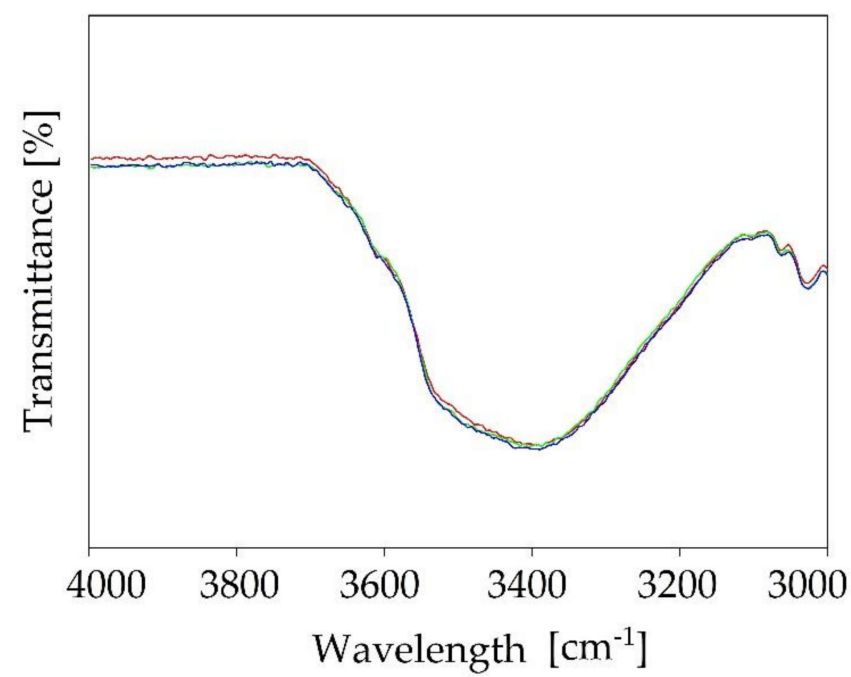

(b)

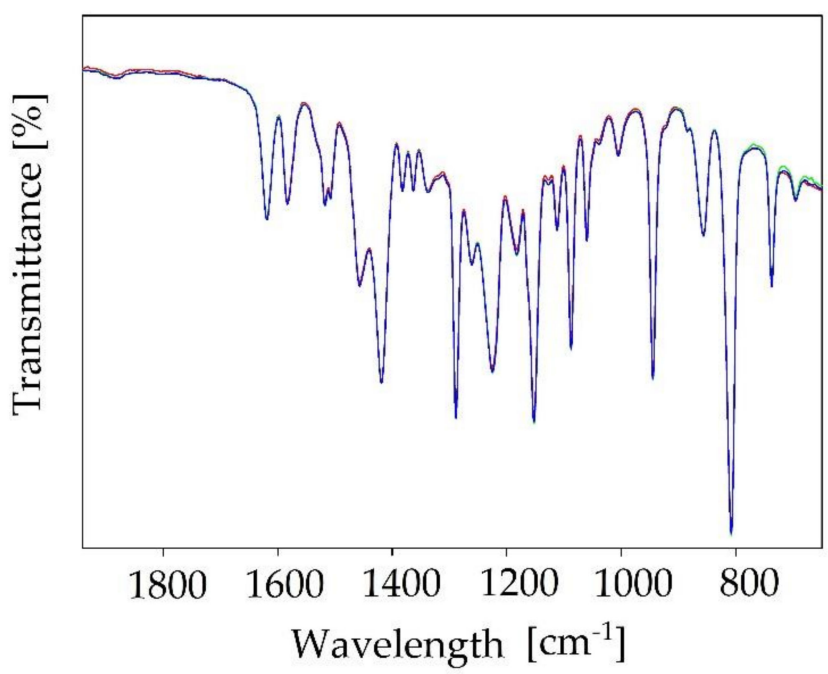

(c)

Figure 6. FT-IR spectrums from optimization of the amount of thymol (Th) to effective removal of HMF from the model fermentation broth and simultaneous formation of DES, (a) all spectrum; (b) zoom spectrum at 4000-3000 cm ${ }^{-1}$; (c) zoom spectrum at $1650-850 \mathrm{~cm}^{-1}$.

\section{Conclusions}

The performed research allowed us to conclude, that the management of post-dark fermentation broth is possible with the application of combined processes of biorefining and photo fermentation, under model conditions. It is possible to reconcile the conflicting interests regarding FA, AA, FF, HMF and LA occurrence. The residual mono sugars present in the broth were successfully converted into DESs precursors. The authors presented a new approach to catch fermentation inhibitors, which consisted in extracting the inhibitors using only the added HBD. Owing to this approach, it is possible to simultaneously purify the medium from inhibitors after photo fermentation and produce solvents based on DES.

In addition, the optimization of conversion conditions allowed to obtain hydrogen in three out of four tested compilations. This approach allows increasing the amount of obtained hydrogen, by even $819 \mathrm{~mL}_{\mathrm{H} 2} / \mathrm{L}$ medium after DF in FA optimized broth. The literature describes photo fermentation with the efficiency range from $168.7 \pm 14 \mathrm{~mL}_{\mathrm{H} 2} / \mathrm{L}$ to $914.1 \pm 8 \mathrm{~mL}_{\mathrm{H} 2} / \mathrm{L}$ calculated using the Gompertz model and measured using the 
means of gas chromatography [41-43]. The obtained results are promising, as to the best knowledge of the Authors, the presented approach has not yet been published in the literature. The results are obtained in model conditions, therefore, research in real conditions is identified as the future direction of the research.

Supplementary Materials: The following are available online at https://www.mdpi.com/article/10 .3390/en14196268/s1, Figure S1: FT-IR spectrums from optimization of the kind of HBD (a) Th; (b) M; (c) LC; (d) E used for effective removal of FF from the model fermentation broth and simultaneous formation of DES, Figure S2: FT-IR spectrums from optimization of the kind of HBD (a) Th; (b) M; (c) LC; (d) E used for effective removal of HMF from the model fermentation broth and simultaneous formation of DES, Figure S3: FT-IR spectrums from optimization of the kind of HBD (a) Th; (b) M; (c) LC; (d) E used for effective removal of LA from the model fermentation broth and simultaneous formation of DES, Figure S4: FT-IR spectrums from optimization of the kind of HBD (a) Th; (b) M; (c) LC; (d) E used for effective removal of FA from the model fermentation broth and simultaneous formation of DES.

Author Contributions: Conceptualization, K.K., P.M.-C., E.S. and J.G.; data curation, P.M.-C. and E.S.; formal analysis, K.K., P.M.-C. and E.S.; funding acquisition, K.K.; investigation, K.K. and E.S.; methodology, K.K., P.M.-C. and E.S.; project administration, K.K.; resources, P.M.-C.; validation, P.M.-C. and E.S.; visualization, K.K. and E.S.; writing-original draft, K.K., P.M.-C. and E.S.; writingreview and editing, K.K. and J.G. All authors have read and agreed to the published version of the manuscript.

Funding: Subsidy for research and development and related tasks for the development of young scientists "Minigrants B/D Subsidy 2021", Ministry of Education and Science, Poland, project number 035156 .

\section{Institutional Review Board Statement: Not applicable.}

Informed Consent Statement: Not applicable.

Conflicts of Interest: The authors declare no conflict of interest. The funders had no role in the design of the study; in the collection, analyses or interpretation of data; in the writing of the manuscript or in the decision to publish the results.

\section{References}

1. Vijayaraghavan, K.; Ahmad, D. Biohydrogen generation from palm oil mill effluent using anaerobic contact filter. Int. J. Hydrog. Energy 2006, 31, 1284-1291. [CrossRef]

2. Dincer, I.; Acar, C. Review and evaluation of hydrogen production methods for better sustainability. Int. J. Hydrog. Energy 2015, 40, 11094-11111. [CrossRef]

3. Tang, G.-L.; Huang, J.; Sun, Z.-J.; Tang, Q.-Q.; Yan, C.-H.; Liu, G.-Q. Biohydrogen production from cattle wastewater by enriched anaerobic mixed consortia: Influence of fermentation temperature and pH. J. Biosci. Bioeng. 2008, 106, 80-87. [CrossRef] [PubMed]

4. Kucharska, K.; Hołowacz, I.; Konopacka-Łyskawa, D.; Rybarczyk, P.; Kamiński, M. Key issues in modeling and optimization of lignocellulosic biomass fermentative conversion to gaseous biofuels. Renew. Energy 2018, 129, 384-408. [CrossRef]

5. Słupek, E.; Makoś, P.; Kucharska, K.; Gębicki, J. Mesophilic and thermophilic dark fermentation course analysis using sensor matrices and chromatographic techniques. Chem. Pap. 2020, 74, 1573-1582. [CrossRef]

6. Singh, R.; White, D.; Demirel, Y.; Kelly, R.; Noll, K.; Blum, P. Uncoupling fermentative synthesis of molecular hydrogen from biomass formation in Thermotoga maritima. Appl. Environ. Microbiol. 2018, 84, 1-16. [CrossRef]

7. Zheng, Y.; Zhao, J.; Xu, F.; Li, Y. Pretreatment of lignocellulosic biomass for enhanced biogas production. Prog. Energy Combust. Sci. 2014, 42, 35-53. [CrossRef]

8. $\quad$ Łukajtis, R.; Hołowacz, I.; Kucharska, K.; Glinka, M.; Rybarczyk, P.; Przyjazny, A.; Kamiński, M. Hydrogen production from biomass using dark fermentation. Renew. Sustain. Energy Rev. 2018, 91, 665-694. [CrossRef]

9. Łukajtis, R.; Rybarczyk, P.; Kucharska, K.; Konopacka-Łyskawa, D.; Słupek, E.; Wychodnik, K.; Kamiński, M. Optimization of saccharification conditions of lignocellulosic biomass under alkaline pre-treatment and enzymatic hydrolysis. Energies 2018, 11, 886. [CrossRef]

10. Kucharska, K.; Łukajtis, R.; Słupek, E.; Cieśliński, H.; Rybarczyk, P.; Kamiński, M. Hydrogen production from energy poplar preceded by MEA pre-treatment and enzymatic hydrolysis. Molecules 2018, 23, 3029. [CrossRef]

11. Mussatto, S.I.; Fernandes, M.; Mancilha, I.M.; Roberto, I.C. Effects of medium supplementation and pH control on lactic acid production from brewer's spent grain. Biochem. Eng. J. 2008, 40, 437-444. [CrossRef]

12. Yokoi, H.; Saitsu, A.; Uchida, H.; Hirose, J.; Hayashi, S.; Takasaki, Y. Microbial hydrogen production from sweet potato starch residue. J. Biosci. Bioeng. 2001, 91, 58-63. [CrossRef] 
13. Redondas, V.; Gómez, X.; García, S.; Pevida, C.; Rubiera, F.; Morán, A.; Pis, J.J. Hydrogen production from food wastes and gas post-treatment by CO2 adsorption. Waste Manag. 2012, 32, 60-66. [CrossRef]

14. Cheng, J.; Ding, L.; Xia, A.; Lin, R.; Li, Y.; Zhou, J.; Cen, K. Hydrogen production using amino acids obtained by protein degradation in waste biomass by combined dark- and photo-fermentation. Bioresour. Technol. 2015, 179, 13-19. [CrossRef] [PubMed]

15. Xing, Y.; Li, Z.; Fan, Y.; Hou, H. Biohydrogen production from dairy manures with acidification pretreatment by anaerobic fermentation. Environ. Sci. Pollut. Res. 2010, 17, 392-399. [CrossRef] [PubMed]

16. Azbar, N.; Dokgöz, F.T.; Keskin, T.; Eltem, R.; Korkmaz, K.S.; Gezgin, Y.; Akbal, Z.; Öncel, S.; Dalay, M.C.; Gönen, Ç.; et al. Comparative Evaluation of Bio-Hydrogen Production From Cheese Whey Wastewater Under Thermophilic and Mesophilic Anaerobic Conditions. Int. J. Green Energy 2009, 6, 192-200. [CrossRef]

17. Levin, D.B.; Islam, R.; Cicek, N.; Sparling, R. Hydrogen production by Clostridium thermocellum 27405 from cellulosic biomass substrates. Int. J. Hydrog. Energy 2006, 31, 1496-1503. [CrossRef]

18. Li, Q.; Yang, M.; Wang, D.; Li, W.; Wu, Y.; Zhang, Y.; Xing, J.; Su, Z. Efficient conversion of crop stalk wastes into succinic acid production by Actinobacillus succinogenes. Bioresour. Technol. 2010, 101, 3292-3294. [CrossRef] [PubMed]

19. Kim, D.Y.; Yim, S.C.; Lee, P.C.; Lee, W.G.; Lee, S.Y.; Chang, H.N. Batch and continuous fermentation of succinic acid from wood hydrolysate by Mannheimia succiniciproducens MBEL55E. Enzyme Microbial Technol. 2004, 35, 348-653. [CrossRef]

20. Jönsson, L.J.; Martín, C. Pretreatment of lignocellulose: Formation of inhibitory by-products and strategies for minimizing their effects. Bioresour. Technol. 2016, 199, 103-112. [CrossRef]

21. Lay, J.J.; Lee, Y.J.; Noike, T. Feasibility of biological hydrogen production from organic fraction of municipal solid waste. Water Res. 1999, 33, 2579-2586. [CrossRef]

22. Evvyernie, D.; Yamazaki, S.; Morimoto, K.; Karita, S.; Kimura, T.; Sakka, K.; Ohmiya, K. Identification and characterization of Clostridium paraputrificum M-21, a chitinolytic, mesophilic and hydrogen-producing bacterium. J. Biosci. Bioeng. 2000, 89, 596-601. [CrossRef]

23. Wu, X.; Zhu, J.; Dong, C.; Miller, C.; Li, Y.; Wang, L.; Yao, W. Continuous biohydrogen production from liquid swine manure supplemented with glucose using an anaerobic sequencing batch reactor. Int. J. Hydrogen Energy 2009, 34, 6636-6645. [CrossRef]

24. Karmann, S.; Panke, S.; Zinn, M. Fed-Batch Cultivations of Rhodospirillum rubrum Under Multiple Nutrient-Limited Growth Conditions on Syngas as a Novel Option to Produce Poly(3-Hydroxybutyrate) (PHB). Front. Bioeng. Biotechnol. 2019, 7, 59. [CrossRef] [PubMed]

25. Ghimire, A.; Frunzo, L.; Pirozzi, F.; Trably, E.; Escudie, R.; Lens, P.N.L.; Esposito, G. A review on dark fermentative biohydrogen production from organic biomass: Process parameters and use of by-products. Appl. Energy 2015, 144, 73-95. [CrossRef]

26. He, D.; Bultel, Y.; Magnin, J.P.; Roux, C.; Willison, J.C. Hydrogen photosynthesis by Rhodobacter capsulatus and its coupling to a PEM fuel cell. J. Power Sources 2005, 141, 19-23. [CrossRef]

27. Akerman, N.H.; Butterfield, D.A.; Huber, J.A. Phylogenetic diversity and functional gene patterns of sulfur-oxidizing subseafloor Epsilonproteobacteria in diffuse hydrothermal vent fluids. Front. Microbiol. 2013, 4, 185. [CrossRef]

28. Kucharska, K.; Cieśliński, H.; Rybarczyk, P.; Słupek, E.; Łukajtis, R.; Wychodnik, K.; Kamiński, M. Fermentative conversion of two-step pre-treated lignocellulosic biomass to hydrogen. Catalysts 2019, 9, 858. [CrossRef]

29. Akobi, C.; Hafez, H.; Nakhla, G. The impact of furfural concentrations and substrate-to-biomass ratios on biological hydrogen production from synthetic lignocellulosic hydrolysate using mesophilic anaerobic digester sludge Furfural:sugars exerted a greater effect on $\mathrm{H} 2$ inhibition than f. Bioresour. Technol. 2016, 221, 598-606. [CrossRef]

30. Hames, B.; Scarlata, C.; Sluiter, A. Determination of Protein Content in Biomass; National Renewable Energy Laboratory: Golden, CO, USA, 2008.

31. Tani, K.; Kanno, R.; Ji, X.; Hall, M.; Yu, L.; Kimura, Y.; Madigan, M.T.; Humbel, B.M. Cryo-EM Structure of the Photosynthetic LH1-RC Complex from Rhodospirillum rubrum. BioRxiv 2021, 1-10. [CrossRef]

32. Kuever, J.; Rainey, F.A.; Widdel, F. Desulfuromonas. Bergey Man. Syst. Archaea Bact. 2015, 1-7. [CrossRef]

33. Sorokin, C.; Krauss, R.W. The Effects of Light Intensity on the Growth Rates of Green Algae. Plant Physiol. 1958, 33, 109-113. [CrossRef] [PubMed]

34. $\mathrm{Wu}, \mathrm{K} . J . ;$ Chang, J.S. Batch and continuous fermentative production of hydrogen with anaerobic sludge entrapped in a composite polymeric matrix. Process Biochem. 2007, 42, 279-284. [CrossRef]

35. Scholz, M.; Frank, B.; Stockmeier, F.; Fal1, S.; Wessling, M. Techno-economic analysis of hybrid processes for biogas upgrading. Ind. Eng. Chem. Res. 2013, 52, 16929-16938. [CrossRef]

36. Zhang, Q.; De Oliveira Vigier, K.; Royer, S.; Jérôme, F. Deep eutectic solvents: Syntheses, properties and applications. Chem. Soc. Rev. 2012, 41, 7108-7146. [CrossRef]

37. Słupek, E.; Makoś-Chełstowska, P.; Gębicki, J. Removal of siloxanes from model biogas by means of deep eutectic solvents in absorption process. Materials 2021, 14, 241. [CrossRef] [PubMed]

38. Makoś, P.; Słupek, E.; Gębicki, J. Hydrophobic deep eutectic solvents in microextraction techniques-A review. Microchem. J. 2020, 152, 104384. [CrossRef]

39. Makoś, P.; Słupek, E.; Gębicki, J. Extractive detoxification of feedstocks for the production of biofuels using new hydrophobic deep eutectic solvents-Experimental and theoretical studies. J. Mol. Liq. 2020, 308, 113101-113112. [CrossRef] 
40. Li, K.; Jin, Y.; Jung, D.; Park, K.; Kim, H.; Lee, J. In situ formation of thymol-based hydrophobic deep eutectic solvents: Application to antibiotics analysis in surface water based on liquid-liquid microextraction followed by liquid chromatography. J. Chromatogr. A 2020, 1614, 460730. [CrossRef]

41. Ghimire, A. Dark fermentative biohydrogen production from organic waste and application of by-products in a biorefinery Anish Ghimire To cite this version: HAL Id : Tel-01404689 Biofuels Waste Treatment Waste Biomass based Biore fi nery Energy and Sustainability Bio. PhD Thesis, Université Paris-Est, Paris, France, 2016.

42. Kapdan, I.K.; Kargi, F. Bio-hydrogen production from waste materials. Enzyme Microb. Technol. 2006, 38, 569-582. [CrossRef]

43. Buchanan, B.B. 6 Ferredoxin-Linked Carboxylation Reactions. Enzymes 1972, 6, 193-216. 